\title{
Evolution of sedentary pastoralism in south India: case study of the Kangayam grassland
}

\author{
Anil Kumar ${ }^{*}$, S Natarajan², Nagaratna B Biradar ${ }^{3}$ and Brij K Trivedi ${ }^{1}$
}

\footnotetext{
* Correspondence: anil.igfri@gmail. com

Full list of author information is available at the end of the article
}

\begin{abstract}
Kangayam grassland in the tropical region of south India has been sustainably managed for over one hundred and fifty years. In a region with meagre rainfall, growing grass is the farmers' main vocation. Between 1855 and 1881, the majority of government 'wastelands' were given on lease to farmers who organized the land into grazing paddocks and fenced with hedges of Balasmodendron berryi. Numerous wells were dug in the grazing lands to provide water for drinking to animals and to some extent for irrigation. Between July and February, the animals are exclusively grazed by rotating between paddocks. The grazing lands are cultivated every 4 to 5 years and sorghum is sown and made into hay for animal feeding between March and June. In several places, the Cenchrus dominated grassland is also sown with legumes like Phaseolus trilobus to improve the quality of forage. Security of land tenure coupled with technological interventions has sustained the productive capacity of the grassland for over a century. The grassland also has a stable human population and healthy female to male ratio. It offers a model for replication elsewhere under similar low rainfall conditions.
\end{abstract}

Keywords: Grazing paddocks India, Kangayam grassland, sustainable development, security of land tenure

\section{Background}

The livelihoods of poor livestock keepers in India primarily depend on the productivity of edible biomass available from common property resources (CPRs) like village commons, the roadsides, along railway tracts, canals, bunds etc. A pro-poor livestock development programme should focus on rejuvenating these resources through enabling policy measures and appropriate technology interventions which may increase the productivity of these lands, thereby increasing the livestock productivity dependant on them. Although there exists a range of technologies to improve the productivity of grazing lands like reseeding with grasses, introduction of leguminous species, rotational grazing etc., there are few reported cases of their application under field conditions and of people deriving benefits. However, the Kangayam region in Tamil Nadu state in peninsular India has a range of technological and social practices applied for over a century, which have made the grassland a sustainable production system (Figure 1). The collective actions of people in approximately 4,000 sq $\mathrm{km}$ of a rain-shadow area have ensured a secure livelihood for people where grass is the main crop and livestock rearing is an important income generating activity. Ironically, such a well-managed

(c) 2011 Kumar et al; licensee Springer. This is an Open Access article distributed under the terms of the Creative Commons Attribution License (http://creativecommons.org/licenses/by/2.0), which permits unrestricted use, distribution, and reproduction in any medium provided the original work is properly cited. 


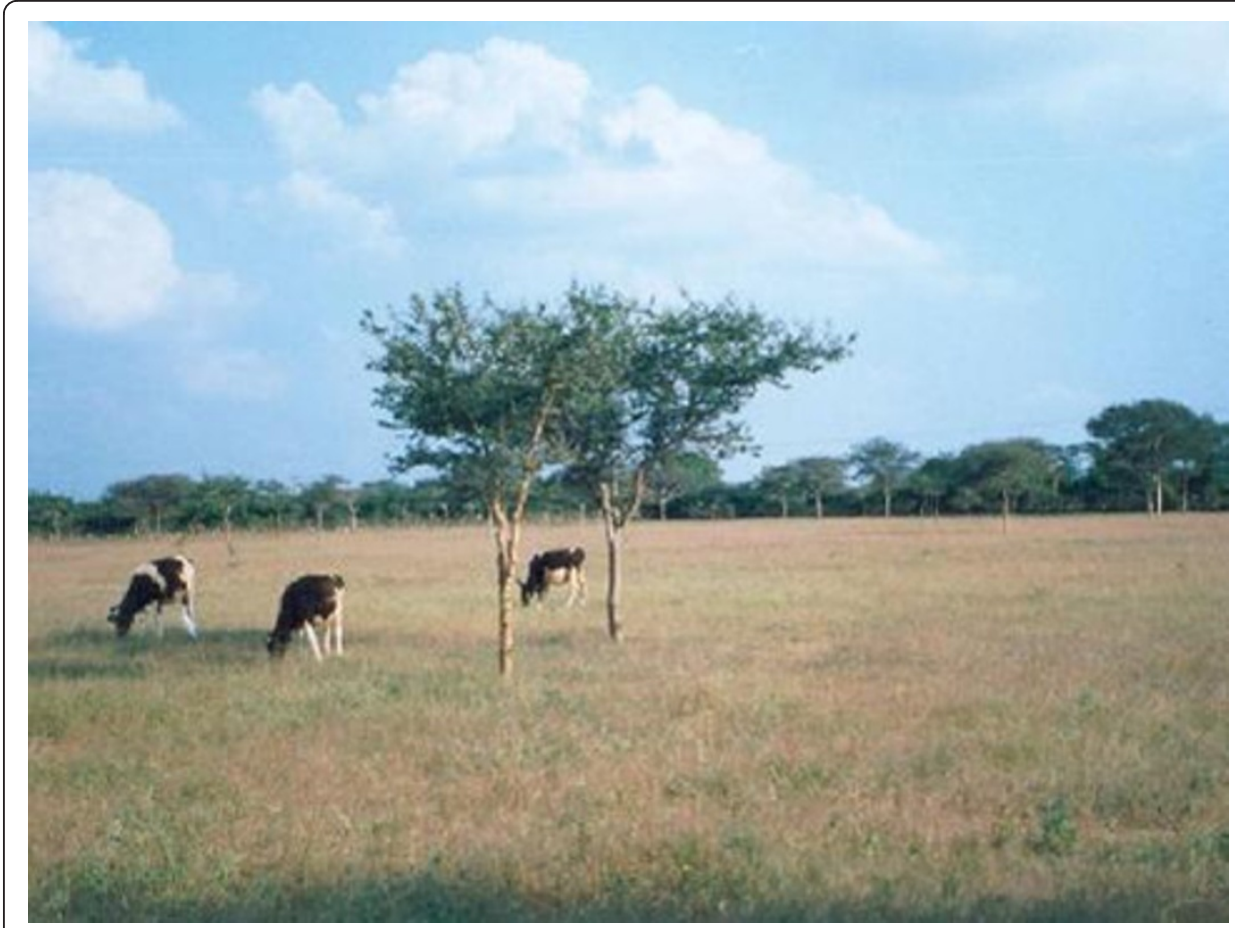

Figure 1 Grazing land in the Kangayam region.

grassland production system has not been publicized beyond its immediate vicinity and, thus obscured from policy makers and field workers who remain on the lookout for a successful model of sustainable grazing land management. Foundation for Ecological Security (2009) has also observed that the restoration of the degraded commons is akin to land distribution for the poor and helps in reducing the vulnerability of poor livestock-keepers to environmental and economic uncertainties, and to stabilise the livestock sector. Improved commons also provide a strong ecological foundation that can spur poor livestock-keepers to become more successful in the livestock sector.

We argue here that the first and the foremost factor in making a wasteland into a sustainable production system is to instill a sense of ownership among the farmers. Wastelands in India generally refer to non-agricultural areas which have various limitations. The term degraded and wastelands are also commonly used and the area under these have been reported to be $114 \mathrm{~m}$ ha (Maji et al. 2010) in India. Being assigned the ownership rights encourages the farmers to invest in land and it takes a few generations to improve the production capacity of a wasteland. Therefore, security of tenure is of paramount importance. The ownership, be it vested in an individual farmer or in a community in a real sense has done wonders in improving the productivity of the land and devising the benefit-sharing mechanisms among the stakeholders. The 'tragedy of the commons' (Hardin 1968) is that in most of the cases the community does not have effective control of the CPRs which have been usurped by the unscrupulous elements in the society. However, there is evidence (Archana and Sharma 2009) that wherever the society has risen up to take up the common cause by evicting the illegal encroachers, the CPRs have been rejuvenated and an acceptable benefit sharing mechanisms arrived at. For example, in the Shajapur district of Madhya Pradesh 
(India), revenue wastelands in the village were taken on lease for 99 years by the Tree Growers' Cooperative Societies. Through social fencing, the wastelands were regenerated to satisfy the feed and fodder requirements of the beneficiaries. There was an increase in number of cattle, buffalo and goats kept by the farmers, while the landless households were the largest beneficiaries.

\section{Study Area}

The Kangayam region being located in the rain-shadow region of south India is a drought-prone area where pasture grass is the main crop and livestock rearing a major occupation of the farmers. Almost every field in the Kangayam region has a live hedge of Balsamodendron berryi which helps secure the animals grazing inside the field. This frees the farmers from having to tend the animals throughout the day, and the farmers use their time productively in other vocations. The innovation lies in recognizing the use of the B. berryi plants as live fences. Maintenance of the live fences entails a collective responsibility in keeping away the goats, which has been achieved by a decision by the panchayats (democratically elected body at village level) in the past in restricting the population of goats and imposing a heavy penalty on those who infringed the rule. Over a period of one hundred and fifty years the grasslands have evolved into an excellent productive system, which has sustained the livelihood of farmers and has helped cope with the frequent droughts that the area faces. Due to this harmony of living with the inherent limitation of the system there has been little degradation of the land and limited out migration of people. The social issues also resolved in a way that the long-term sustainability of the system was strengthened. A grazing area should be large enough for the livestock to graze and roam around so that the re-germination capacity of the grasses is not adversely affected. Therefore, to maintain the ratio of livestock ownership to land, the people had to limit the human population growth, if the livestock:human ratio was not to be reduced. The people have consciously limited their family sizes to either one or two offspring for at least the last three to four generations and hence the human population is almost stable over a hundred year period. Moreover, the equality of gender and their empowerment has been a hallmark of this region and unlike most other parts of India; there are more females than males here.

\section{Purpose of the study}

A study was initiated by the Indian Grassland and Fodder Research Institute, Jhansi, India in 2002 to study the livestock rearing practices prevalent in the Kangayam region for over one hundred year. The Kangayam region is known for its prized Kangayam breed of cattle developed by one individual called Rai Bahadur Nallathambi Sarkarai of the Pattagar family in the late $19^{\text {th }}$ century (Gunn 1909). Kangayam cattle were established as an important draft breed in south India. Although the Kangayam breed is well known in south India, very little information is available about the grazing tracts and the animal production system where it was developed. A second reason for initiating this study arose from the policy level, where discussions are often held about the development of grazing land and community pasture in the country. It is said that technologies exist to revitalize the grasslands but sustainable community management and equitable distribution of benefits could not be achieved because of conflicts and vested interests. Questions are also asked at the policy level if there is a successful 
model which could be replicated elsewhere. It is with these issues at hand that a study was initiated in the Kangayam region to pinpoint the key to success of the sustainable system which is difficult to find in tropical regions.

\section{Methods of study}

We started by talking to the people at Tamil Nadu Agricultural University at Coimbatore and attending a few meetings of the state government officials. From the discussions five districts namely, Coimbatore, Erode, Karur, Nammakal and Dindigul were shortlisted. The area was traversed extensively and it was observed that Nammakal and Dindigul did not have significant area under the paddock system of grassland. Thus, we concluded that the Kangayam grassland is spread over 9 blocks in three districts (Coimbatore, Erode and Karur) in 3,841 sq km. The lowest administrative unit at village level is panchayat, a democratically elected body. A few panchayats make a block and a few blocks make a taluk. Several taluks constitute a district and several districts make a state/province.

We began by talking to people of the region about the history and evolution of the paddock system of grassland. From these discussions we developed a questionnaire to gather data regarding the landholding, cropping pattern, livestock rearing practices etc. Later on, more socio-economic parameters were added as it came to our notice that there were very few households which had small children. We started asking people about the number of siblings they had, and their parents and grandparents had. The basic statistics about the human population were collected from government departments. In 1800 the whole area was in Coimbatore district from which Erode and Karur districts were later carved out. In the present study, the population figures and area occupied were constructed for Dharapuram taluk (area 2,165 sq km, which was in Coimbatore district in 1800, (Anonymous 1908) to highlight the change in human population and area occupied since 1800 .

A study of herbaceous vegetation was carried out through line interception $(2 \mathrm{~m})$ method and importance value index (IVI) was computed for all species encountered in the fields using the relative density (RD), relative dominance (RDom) and relative frequency (RF) (Kershaw and Looney 1985; Roberts-Pichette and Gillespie 1999). For woody species quadrats of $100 \mathrm{~m}^{2}$ was adopted for the purpose. The diameter of the woody vegetation was measured at breast height (dbh). The biomass was calculated by taking at least five quadrats of $4 \mathrm{~m}^{2}$ from each site. Biomass in the grazing paddocks was estimated at 12 sites in the grassland. Similarly, soil samples were taken from 8 sites to assess their physical-chemical properties.

The livestock population was taken from the $17^{\text {th }}$ Livestock Census (GOI 2003). The livestock population was converted into standard Adult Cattle Units (ACU) (Patel and Kumbhara 1983).

\section{Location}

The grasslands of the Kangayam region are spread over three districts of Tamil Nadu state in south India, covering an area of approximately 3,841 sq km. The grassland is located between $77^{\circ} 17^{\prime \prime} \mathrm{E}$ and $77^{\circ} 55^{\prime \prime} \mathrm{E}$ longitude and $10^{\circ} 44^{\prime \prime} \mathrm{N}$ and $11^{\circ} 03^{\prime \prime} \mathrm{N}$ latitude (Figure 2). The east-west spread of the grassland is $70 \mathrm{~km}$ and the north-south spread is $45 \mathrm{~km}$. The region lies east of the Western Ghats in the rain-shadow area. 


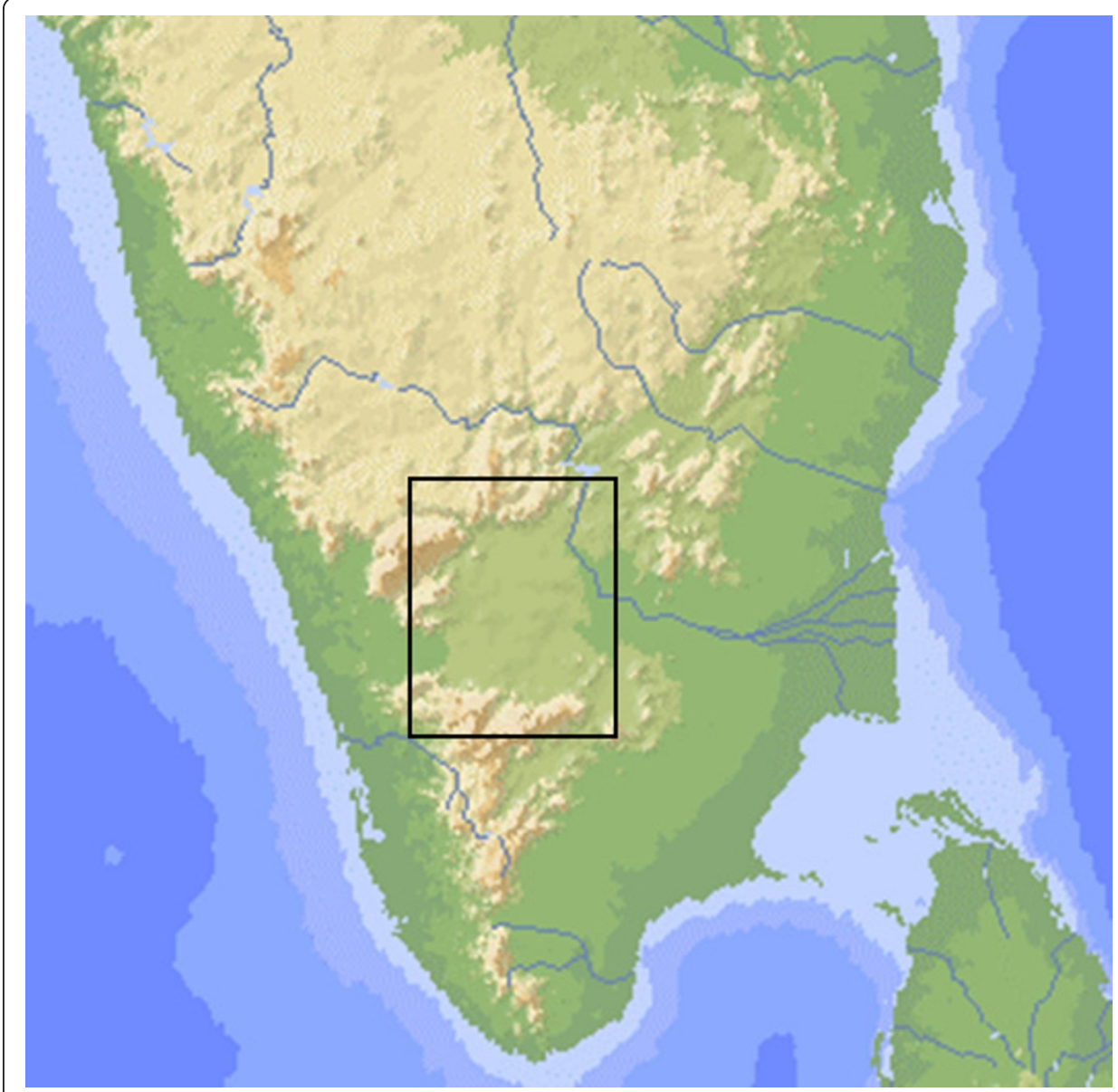

Figure 2 Geographical location of the Kangayam region in south India

The three districts which include the grassland are Erode (2,217 sq km, 5 blocks), Karur (976 sq km, 2 blocks) and Coimbatore (648 sq km, 2 blocks).

\section{Historical development of the grassland}

The Kangayam grasslands were located historically in the Kongu region which corresponds to the present day districts of Coimbatore, Erode and Karur of Tamil Nadu state in south India. When the British East India Company took over the administration of the region in 1799 after the fall of its ruler Tipu Sultan, all the three districts mentioned above formed part of Coimbatore district. The Kangayam grassland was in one of the earliest territorial divisions of the ancient home of the Tamils (Nicholson 1887; 1898). The Kongu region is sheltered by the series of mountain ranges of considerable height such as the Palani hills, the Kolli and Panchamalai hills, the Serveroys and the Talaimalai hills, the Anamalais and the Nilgiries (Ramamurthy 1986). According to Tamil tradition the Tamil land had extended up to 'Vada Venkatam'. The Tamil term 'Venkatam' can be split as Vem + Kadam, which means the great desert-like land of excessive heat. Thus, 'Vada Venkatam' indicates a vast belt that stretches across the Deccan of which the western extension would have reached up to the Western Ghats. The plateau between the Western Ghats and the Coromandel coast in the east has a 
general elevation of $200 \mathrm{ft}$, but tends to become higher and more rugged as the Ghats are approached. Scarcity of water has foiled attempts at habitation (Ramamurthy 1986).

The original inhabitants of the Kongu region were Eyinar, Kurumbar and the Vedar tribes. In the Sangam age in the first three centuries of the Christian era, a new set of tribes appeared in the region and subdued the original inhabitants. Among these tribes, the Kongars were pastoral people who had to put up severe fights to get a foothold in the region. In the poems of Sangam literature, the advent of the Kongars is described as the march of a pastoral people in search of water and pasture. Kongars suffered from scarcity of water in their native home and they had to dig deep by cutting hardbound rocks for a small quantity of water (Ramamurthy 1986). There are many other references about the people of the Kongu country from the Sangam literature from which we learn that the Kongars possessed numerous herds of cattle.

From the earliest times until the acquisition of the region in 1799 by the British, the human population remained low because of incessant wars, famines and occurrence of frequent drought in the region. Quoting surveys conducted by the British officers during that period, Nicholson (1887) described the country as covered with thorns and stones.

In the initial days of British administration in the early nineteenth century, farmers were encouraged to keep their land under pasture by providing them two kinds of incentive. The first, ayen pillu (remission in tax) was reduction of three-fourths of the assessment on lands held for grazing, such reduction being limited to one-fifth of the farmers' holding. The other was paravu pillu, which was a grazing rent, but it was rather a mode of assessment than a remission; public wasteland could be held for grazing at one-fourth the assessment so long as no one wished for the land for cultivation at the full rate (Nicholson 1887).

The population at the beginning of eighteenth century was low. In the Dharapuram taluk (as of 1800), occupying over 2,000 sq km, the population density was only 32 persons per sq $\mathrm{km}$ and the total occupied area was only 27.3 percent (Table 1 ). Nicholson (1887) has quoted the reports of Buchanan who surveyed the area in 1800 and Campbell in 1832 and concluded that the best lands in the district were under cultivation early in the century, and only the poorer sorts were left untilled. The farmers were compelled to rent more land than they were able to cultivate (Buchanan 1807). This, so-called grasslands, part of which were held on patta (lease), part formed the

Table 1 Change in human population and area occupied in Dharapuram taluk from 1800 to 1991

\begin{tabular}{lllrrr}
\hline Year & Human population & Human density $(\mathbf{n o} / \mathbf{s q} \mathbf{~ k m})$ & \multicolumn{3}{c}{ Occupied area $(\mathbf{h a})$} \\
\cline { 4 - 6 } & & & Dry area & Wet area & Total \\
\hline 1991 & 395940 & 183 & & & $195786^{*}$ \\
1881 & 195232 & 90 & 185799 & 3304 & 189103 \\
1851 & 147224 & 68 & 121165 & 2989 & 124110 \\
1800 & 70176 & 32 & 57755 & 1425 & 59158 \\
& & & $(26.7)$ & $(0.7)$ & $(27.3)$ \\
\hline
\end{tabular}

* = Total area - (forest + barren \& uncultivable area+ non agricultural use).

Note: The human population of Dharapuram taluk in 1881 was $11.8 \%$ of the Coimbatore district. Based on this figure, the population before 1881 was derived from the population of Coimbatore district. Statistics for area occupied in 1861 was used to estimate the area occupied per person. Area occupied prior to 1861 was estimated by multiplying the area occupied per person (1861) and the human population of the respective years. Figures in parentheses indicate the percent of above. 
large area of poor lands that were classed as government waste and were taken on lease only after 1855 . The population and prices increased rapidly after 1855 , and the farmers' regular farm land was converted from pasture to cultivation, because it became more profitable. Additionally, farmers took more government wastelands on lease for grazing their animals. Nicholson (1887) noted that by that time government wastelands had also almost disappeared. Thus, between 1855 and 1887, almost all of the government wastelands were leased by the farmers and consolidated as grazing paddocks.

During the $19^{\text {th }} \mathrm{C}$, farmers were forced to rent more land than they could till (Buchanan 1807), so that the British colonizers would get more revenue. Between 1800 and 1881, was the period of expansion. The increase in human population resulted in 87.3 percent of the area occupied by the people with a peak population density of 96 persons per sq $\mathrm{km}$ (1871), although it declined to 90 persons per sq $\mathrm{km}$ in 1881 because of severe famine that occurred in 1877-78. Beyond 1881, there was little land left for expansion. Thereafter was period of consolidation and improving the land by digging wells and erecting live fences which will be discussed later.

By $1881,87.4 \%$ of the land was occupied, after which there was little scope for expansion as one hundred years later in 1991 the total area occupied excluding forest, barren and uncultivable area and non agricultural use was $89.7 \%$ (Table 1).

While talking to the people of the region, they emphasized that the paddock system of grassland management has been in vogue 'since time immemorial', but in fact it had developed in a short span of time between 1855 and 1881. That is, four to six generations before the present. Local inhabitants can hardly recall the process of expansion of area under occupation, although in a few places old persons did tell us that English rulers had given patta to their forefathers. The technology of live fencing around garden lands using Euphorbium tirucalli, Euphorbium antiquorum, and Balsamodendron berryi was known to people even in 1800 (Buchanan 1807). In this paper we ask how the Kangayam grassland has been sustained over one hundred years with an increasing human population which doubled from 90 persons per sq km in 1881 to 183 in 1991 in the case of Dharapuram taluk.

\section{Area and population}

The total human population in the grassland in three districts covering an area of $3,841 \mathrm{sq} \mathrm{km}$ is 764,913 with a population density of 199 persons per sq $\mathrm{km}$ (2001). The human population growth rate in Dharapuram taluk in the erstwhile Coimbatore district between 1800 and 1891 was 1.42 percent p.a. which slowed down in the next one hundred years between $1891-1991$ at $0.45 \%$ p.a., as against 1.45 for the whole of India during the same period (GOI 2009). This indicates a stable human population in this region, which only the advanced western countries can currently boast of. The wisdom of the people and their stated decision to keep families small needs to be appreciated in the context of their fear of fragmenting grazing lands, making them unviable. In the grassland of Karur district, the growth rate in human population between 1931 - 1991 was 0.52 percent p.a. and between 1991 and 2001, the human population actually declined at the rate of 0.09 p.a. In the present study we found that 45 percent of the families had only one child and 40 percent had 2 children. The people in the region pointed out that further fragmentation of grazing lands would make 
them unviable because of high cost of management of fence and limited duration of grazing permitted for the animals. Therefore, couples mostly restrict their family by having only one or two children by undergoing sterilization (mostly the females) irrespective of the sex of the child. This is in contrast with the scenario in most parts of India, or the male dominated society elsewhere in the world, where there is a marked preference for a male child. Historically also, the region has not shown any negative bias towards girl children as can be seen from the population data where there were 1051 females per 1000 male in 1931, 1006 in 1991 and 1010 in 2001 in the grasslands of Karur district (Table 2).

\section{Rainfall and its distribution}

The grassland is located in the rain-shadow area of the Western Ghats which means rainfall is reduced. The shadowing effect of the mountains towards the east of the grassland can be appreciated from the fact that in less than $50 \mathrm{~km}$ distance the total annual rainfall of over 3,000 $\mathrm{mm}$ (along Western Ghats) is reduced to less than $700 \mathrm{~mm}$ annual total in the Kangayam grassland (Table 3). The south-west monsoon (June-September) brings the bulk of rain in the Indian sub continent, but it fails to drench the Kangayam grassland because the rain-laden clouds coming from the Arabian sea are emptied along the Western Ghats, bringing only $191 \mathrm{~mm}$ of rainfall (29\% of the total) and cool breezes in the grassland. Even this meagre rainfall brings life to the grassland and the dormant, grazed tussocks begin sprouting, giving the first flush of the grass crop. The bulk of the rain in the grassland is received during the retreating north-east monsoon (October-January). During this period $330 \mathrm{~mm}$ rain ( $50 \%$ of the total) is received which gives the second flush of grass crop, besides initiating other farm activities. The remaining hot summer months (Feb-May) get only 145 $\mathrm{mm}$ of rainfall (22\% of the total). Thus, a total of $666 \mathrm{~mm}$ annual rainfall is received in the Kangayam grassland. The quantity of rain and its distribution is hardly sufficient for raising the traditional grain crops. But the rainfall distribution and the soil condition encourages healthy growth of grasses. Even the crop that is raised during the north-east monsoon is primarily meant for the livestock, as discussed later.

Soil

The soil of the grassland is red loam and has a sub-soil rich in Kanker gravel which is a calcium-phosphorus compound. This adds to the fertility of the soil by breaking up

Table 2 Human population in grasslands (Aravakurichi and K Parmathi blocks) of Karur district

\begin{tabular}{|c|c|c|c|c|}
\hline & & 2001 & 1991 & 1931 \\
\hline Human population & & 146536 & 147811 & 108420 \\
\hline Male & & 72894 & 73886 & 52820 \\
\hline Female & & 73642 & 74313 & 55520 \\
\hline No of female/1000 male & & 1010 & 1006 & 1051 \\
\hline \multicolumn{5}{|l|}{ Growth rate (\% p.a.) } \\
\hline 1931-1991 & 0.52 & & & \\
\hline $1991-2001$ & -0.09 & & & \\
\hline $1931-2001$ & 0.43 & & & \\
\hline
\end{tabular}


Table 3 Seasonal pattern of rainfall distribution $(\mathrm{mm})$ in different districts

\begin{tabular}{lllll}
\hline Seasonldistricts & Erode & Karur & Coimbatore & Average \\
\hline $\begin{array}{l}\text { Summer } \\
\text { (Feb-May) }\end{array}$ & 149 & 144 & 142 & 145 \\
$\begin{array}{l}\text { S-W monsoon } \\
\text { (Jun-Sept) }\end{array}$ & 128 & 340 & 106 & $(21.7 \%)$ \\
$\begin{array}{l}\text { N-E Monsoon } \\
\text { (Oct-Jan) }\end{array}$ & 340 & 223 & 428 & 191 \\
\hline Total (mm) & 617 & 707 & 675 & $\begin{array}{l}28.7 \%) \\
(49.6 \%)\end{array}$ \\
\hline
\end{tabular}

the continuity and thus providing aeration and greater absorption of moisture, apart from enhancing the dissolved calcium and phosphorus contents for plants. The soil is broken periodically by cultivating a crop once in four to five years.

\section{Vegetation}

A survey was conducted to identify the herbaceous vegetation found in the grassland. There were 8 species of perennial grasses, 6 annual grasses, 9 legumes and 16 forbs present in the grassland.

Importance value index (i.e. structural role of a particular plant species) of herbaceous vegetation indicated that Aristida setacea had the highest IVI (126.9) followed by Cenchrus ciliaris (49.2), Blumea sp. (37.9) and others (Table 4). The average yield of green grass taken from 12 sites in the paddocks in the month of December was 28.48 \pm 3.06 tonne/ha with a dry matter of $34.4 \pm 1.75$ percent. Thus, dry matter yield in the paddocks in the month of December was 9.8 tones/ha. If we take into account the growth after first rain in May-June and also the growth of the grass while under grazing the total dry matter yield per year could be assumed to be 12.5 to 15.0 tones/ha, which is sufficient to meet the dry matter requirement of 6 to 7 ACU constituting 2 cattle and 25 to 30 sheep for 8 months between July and February.

Density of different woody species were also calculated at 10 different sites in the grassland and it was revealed that the A. leucophloea was the predominant tree species (151 trees per ha) with a dbh of $7.16 \pm 1.13 \mathrm{~cm}$. The density of A. leucophloea varied from 56 to 460 trees per ha at different sites. There was also occasional presence of

Table 4 Analytical characters of herbaceous vegetation in Kangayam tract

\begin{tabular}{lllll}
\hline Species & Relative dominance (\%) & Relative density (\%) & Relative frequency (\%) & IVI \\
\hline Aristida setacea & 76.8 & 32.5 & 7.6 & 126.9 \\
\hline Cenchrus ciliaris & 14.1 & 17.5 & 17.6 & 49.2 \\
\hline Brachiaria repens & 2.8 & 7.5 & 11.7 & 22.0 \\
\hline Alysicarpus monilifera & 0.9 & 7.5 & 5.8 & 14.2 \\
\hline Zornia gibbosa & 1.0 & 7.5 & 11.7 & 20.2 \\
\hline Blumea sp. & 2.8 & 17.5 & 17.6 & 37.9 \\
\hline Cyperus sp. & 0.7 & 5.0 & 11.7 & 17.4 \\
\hline Heterotropiums & 0.5 & 2.5 & 5.8 & 8.8 \\
\hline
\end{tabular}

Frequency: no. of plots in which a species occurs/total no. of plots $\times 100$.

Relative density (RD): no. of individual of a species/total no. of individual of all species $\times 100$.

Relative frequency (RF): frequency of a species/total frequency of all species $\times 100$.

Relative dominance (RDom): total basal area of a species/basal area of all species $\times 100$.

Importance value index: IVI $=\mathrm{RD}+\mathrm{RF}+\mathrm{RDom}$ 
Acacia nilotica, A. planiforms, Albizzia amara, Azadirachta indica trees and palmyra (Borassus flabellifer) in the grazing paddocks.

The land use classification which shows area under forest as 0.38 percent, does not give a correct image of the standing trees in the region. In fact, the grassland is better wooded than many other regions with similar rainfall and open grazing areas. Littlewood (1936) reported that Dharapuram taluk where private pasturage was common was possibly one of the best wooded of any agricultural taluk, and the bulk of these trees were grown in private pastures. The Acacia trees in the grazing areas provide shade to the animals from the hot sun, supply nutritious pods ( $14.7 \%$ crude protein) during summer months (Pattabhiraman 1958) and are regularly felled around 9 11 years and sold off, while new plants take root. The tree population is kept at about 150 trees per ha as otherwise the shading effect would lower the yield of grasses. The trunk of the trees is also regularly pruned up to the height of cattle/buffalo so that the animals do not injure themselves with the spines of tree.

\section{Land use and landholding pattern}

The land holding pattern of the Kangayam grassland has been studied by taking the case of Dharapuram taluk (of 1800 AD) which covers over 50 percent of the area under grassland. The Dharapuram taluk comprising five blocks is predominantly agrarian in character. 84.2 percent of the total workforce is engaged in agricultural activities, of which 37.4 percent are cultivators and 46.8 percent are agricultural labourers. The remaining 15.8 percent of the workforce is engaged in other pursuits like handloom weaving, poultry production etc. The distribution of landholdings and the corresponding area under each category with respect to Dharapuram taluk, where detailed data are available, shows that there are still very large areas under big holdings. Only 16.1 percent of the total number of land holdings covers 51.2 percent of the area with a holding of over 4 ha. The net sown area in Dharapuram taluk is 30.3 percent, of which the area under irrigation is $13.1 \%$ (almost all by well) while 17.2 percent is rainfed. Considering the total area sown and the area of land holding, it can be inferred that any holding over 2.5 ha is devoted to pasture, as holdings larger than 2.5 ha are not usually tilled. Thus, about 70 percent of the area is under pasture used for rearing livestock. It means that there are 25,662 holdings covering an area of 135,807 ha at an average of 5.3 ha per holding that are used as pastureland.

When we consider the land use pattern of whole of the grassland covering the three districts, we find that 61.3 percent of the area is under grazing. The percent area under cultivation has remained almost constant over the last 200 years, as Buchanan (1807) reported that only a quarter of the dry fields were under cultivation and in 2002-03 it is still 28.8 percent of the total. The area cropped more than once is meagre (0.16 percent). This means that the area sown could also be potentially used as grazing area after the crop is harvested. Thus, considering land use pattern and land holding together, we can assume that between 60 to 70 percent of the area in the grassland is exclusively devoted for grazing by the livestock. The survey of the farmers in the grassland also revealed that 63.5 percent of the farmers had paddocks of 2 ha or more. 


\section{Role of wells in the grassland}

Wells in the grazing paddocks are used to draw water for animals. After getting the government wastelands on lease between 1855 and 1881, the ryots (peasants) started the process of consolidation by growing live fences and digging new wells. In 1881, there were 9,835 wells which irrigated 18799 ha of land at an average of 1.9 ha per well (Nicholson 1887). By 2002, the number of wells increased by 386 percent to 47,826 . However, the area irrigated by well had increased by only 23.2 percent. Assuming the per unit area irrigated by well to be similar in 2002 as in 1881, total area irrigated by wells in 2002 required 12,117 wells only. Therefore, the remaining 35,709 wells were dug by the farmers in the wastelands held on patta in the last one hundred year. Digging of new wells was also encouraged by the generous loans provided by the British rulers in the form of taccavi advances (Voelcker 1893). The new wells dug were primarily meant to water the animals that remained day in and out for months together between July and February in the grazing paddocks. Voelcker (1893) observed that anything which induces the people to invest money on the land gives them a permanent interest in the continuance of the English rule. DFID (2002) and Gill (1995) have also observed that security of tenure and ownership play an important role in the sustainability of land.

Livestock

The ownership pattern of livestock (Table 5) in the Kangayam grassland indicates that 70 percent of the farmers own 1 to 4 cattle or buffalo, 65 percent own 15 or more sheep and 85 percent of the farmers do not own any goats. The grassland is well known for the Kangayam breed of draft cattle that were earlier used, for drawing water from the wells and ploughing lands. Nowadays, because of mechanization of agriculture, most of the agricultural operations are carried out by tractors and hence the Kangayam cattle have gradually been replaced by crossbred cattle and buffaloes. Vivekanandan (2007) reported that the crossbred cattle population in the Kangayam grassland was $43 \%$ of the total cattle. Although crossbred cattle have become more prevalent in the grassland over the last decade, the farmers pointed out that these cattle require much attention and they would prefer to try indigenous dual purpose breed like Tharparkar which give moderate milk yields up to 5-7 litres and are very tolerant to extreme climatic conditions. Alternatively, the farmers buy growing heifers/dry cows and rear them until calving and then sell off to peri-urban dairies. Buffalo are also

Table 5 Livestock population and other attributes in the grassland

\begin{tabular}{lllll}
\hline & Erode & Karur & Coimbatore & Total \\
\hline & Population & & & 141814 \\
\hline Cattle & 87312 & 25049 & 29453 & 104008 \\
Buffalo & 68534 & 27240 & 8234 & 402340 \\
Sheep & 224383 & 162264 & 15693 & 131172 \\
Goat & 89018 & 23792 & 18362 & 779334 \\
Total & 469247 & 238345 & 71742 & 1019 \\
& & & & 316276 \\
Livestock no/1000 human beings & 1185 & 1427 & 355 & 0.82 \\
Total ACU & 195771 & 78764 & 41742 & 0.64 \\
ACU/ha & 0.88 & 0.81 & & \\
\hline
\end{tabular}


predominant in the Kangayam grassland and they are mostly the graded Murrah buffalo, kept for milk production. There are two breeds of sheep found in the grassland - Coimbatore and Mecheri. The Coimbatore is a woolly breed with a white body and black head while the Mecheri is a hairy breed of sheep, hornless and generally brown in colour (Figure 3). The farmers informed us that over the years the hairy breed of sheep have almost completely replaced the wooly breed because the mutton of Mecheri sheep is more preferred and are in great demand. Moreover, the skin of this breed makes good export quality leather. Sheep are the choice of animal reared in paddocks which are far off and where daily milk collection is not possible. The sheep have flourished in the grassland because they are hardy, less demanding, and take very little of the farmers' time. Once inside the paddock they remain there for months at a time. However, every evening they are herded into a small enclosure inside the paddock ( $5 \times 4.5 \mathrm{~m}$ for 30 sheep) and a dog keeps guard from the predating jackals.

Goats are not preferred animals in the Kangayam grassland as they demand constant attention of their keepers and damage the live fences of B. berryi. Some farmers in Aravakurichi block in Karur district reported that several village panchayats of the area had resolved in the past to banish goats from the region and impose heavy fines on the keepers whose goats were found straying into the grazing paddocks. We noticed very few flocks of goats in the region being grazed along the roadsides. They mostly belonged to the landless people who are from the poorest strata of the society. They earn their living by doing manual work in the fields of other farmers and/or by rearing a few livestock and grazing them on CPRs.

The livestock population in the grassland is presented in Table 6. There are 1019 head of livestock per 1000 people, which indicates a high dependence of people on the livestock for their livelihood. Nicholson (1887) has also observed that pasture growing is often a better speculation than crop growing in this region. The livestock pressure in the grassland is also moderate as there are $0.82 \mathrm{ACU}$ per ha. A report by ILRI

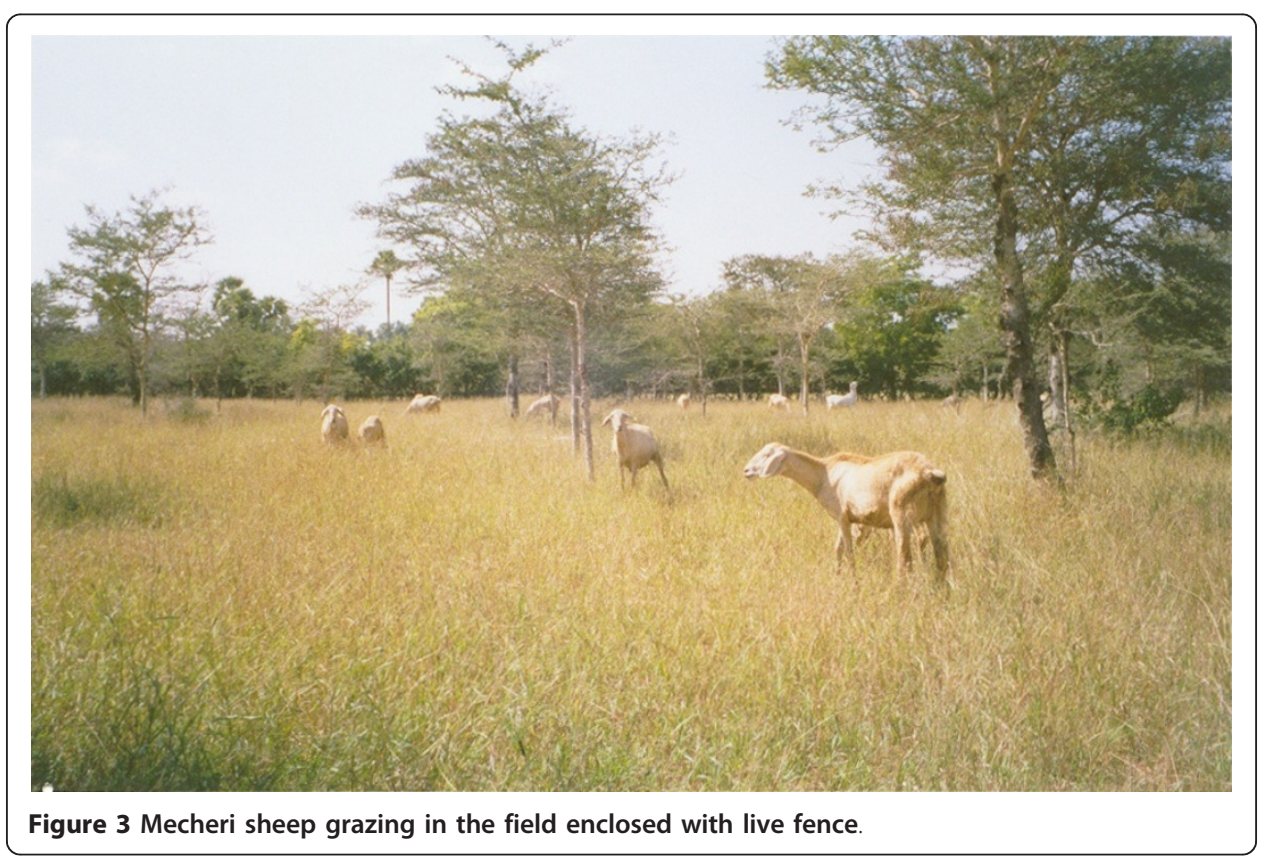


Table 6 Pasture size and livestock distribution in the Kangayam grassland

\begin{tabular}{llll}
\hline SI no & Particulars & Size/number & Percent \\
\hline 1 & Pasture size (ha) & $<2$ & 27.5 \\
& & $2-4$ & 37.5 \\
& & $4-6$ & 20.0 \\
& & $>6$ & 15.0 \\
& & & \\
a) & Distribution of livestock & 0 & 7.5 \\
& Cattle and buffalo (no.) & $1-4$ & 70.0 \\
& & $5-10$ & 12.5 \\
& & $>10$ & 10.0 \\
b) & & $1-10$ & 17.5 \\
& & $11-20$ & 7.5 \\
& & $>21$ & 32.5 \\
& & 0 & 42.5 \\
c) & & $0-5$ & 85.0 \\
& & $>5$ & 12.5 \\
& & & 2.5 \\
\hline
\end{tabular}

Source: Based on survey of 40 farm families in the grassland.

(2000) has also noted that raising livestock in the drier areas and finishing them in more intensive system closer to the final markets may offer the best option to increase productivity and the best opportunity to improve pastoralists' incomes.

\section{Good practices in the grassland}

The management of Kangayam grazing lands today is the culmination of a series of good practices adopted by the farmers over one hundred and fifty years. The paddock system of grassland management has evolved from the wasteland into an organized system of management. The region does not have any community land and all land including grazing lands is under private ownership. Littlewood (1936) observed that in Dharapuram taluk, there is no cultivatable waste, no communal grazing land, and no forest grazing, yet it was one of the best known cattle breeding centres of the Presidency of Madras province in the British era, and its cattle had a higher market value than any other, besides which, it contained some of the best garden cultivation to be seen anywhere in India, as well as an excellent mixed farming. Munro (1931) reported that systematic planting and grazing of grass was practiced in some parts of Coimbatore district e.g., in the taluks of Dharapuram, Erode, Gobichettipalaiyam, Coimbatore and Palladam and the system at its best could be seen in the Kangayam tract of Dharapuram.

The Task Force on Grasslands and Deserts (Planning Commission of India 2007) constituted by the Government of India observed that the importance of rotational or seasonal grazing, some control on free ranging animals, total protection of selected grassland plots to serve as nuclei for seed banks, secure tenure for pastoralists (both resident and nomadic) over pastures, and genetic improvement of livestock (using indigenous breeds, not exotics) have not been taken in to consideration in animal husbandry programmes of the country. The Kangayam grassland fulfills most of the wishes of the Grassland Task Force as explained in this paper.

The Planning Commission of India (2001) also holds the opinion that livestock in the rainfed areas of the country contribute more than 70 percent of the family income 
and hence recommends that sustainable animal production should be promoted in such areas, rather than extending the crops, by improving the production of traditional pastures through improved technologies.

Among other factors that have contributed to the success of the Kangayam grassland, absence of communal grazing land could have been one of the most important factors. It is difficult to find direct evidence, but since the deplorable condition of community grazing lands all over the country is widely noted, we are ready to accept that absence of the communal grazing land may have a positive effect on its sustainability. The Task Force on Grassland and Deserts (Planning Commission 2007) of Government of India has pointed out that in the semi-arid grasslands, the carrying capacity is 1 Adult Cattle Unit (ACU) per ha, but the stocking rates are as high as $51 \mathrm{ACU}$ per ha, while in the arid areas, the carrying capacity is 0.2-05 ACU per ha but the stocking rates are 1 to $4 \mathrm{ACU}$ per ha. Almost all the unoccupied and wastelands in the Kangayam grassland were given on lease (Pillu patta) to the farmers between 1855 and 1891, as previously explained (Table 1). A century ago Nicholson (1887) had also observed that as far as communal grazing land is concerned, there is everything against it. Where there is communal grazing, every peasant in the village naturally claims as large a share of it as possible, with the result that grazing lands are always overstocked, are never given rest and are usually little more than exercise grounds for cattle. $\mathrm{He}$ also reported that when the grazing was regulated, pastures not overstocked, and manure not removed from ground, excellent pasturage should in time be formed.

\section{Use of B. berryi as live hedges}

The importance of Balsamodendron berryi (locally called Mulukiluvai) was known to the people of the region even in 1800. Buchanan had made an extensive survey of the area in 1800 at the direction of the East India Company and the type of fence being used in the fields by the people was a point he covered. This enquiry may have been prompted by the 'Inclosure acts' which were passed in England starting in 1750 which enclosed the open fields in the country (The Isles Project 2010). Between 1750 and 1860, over 5,000 individual 'Inclosure acts' were passed and 21\% of land in England was enclosed, amounting to nearly $28,000 \mathrm{~km}^{2}$. The enclosures made it easier for farmers to try out new farming techniques. Farmers could now invest in new machinery for use on their land, work in one area and not waste time walking between strips of land. The enclosed land was also useful for farmers wanting to experiment with selective breeding and new crops from abroad.

Buchanan (1807) had reported that many of the hedges in Coimbatore district were of Mullukiluvai, which made good fences. Its cuttings were put in the ground between $12^{\text {th }}$ March and $10^{\text {th }}$ April and it quickly took roots. It formed a good fence against cattle but seemed to require a better soil than either Euphorbia tirucalli or Euphorbia antiquorum, which were the most common hedges in the district. Although Buchanan (1807) has reported that Euphorbium tirucalli and Euphorbium antiquorum were more commonly used as fences in the early nineteenth century, we found currently that almost all the paddocks used B. berryi as live fences (Figure 4,5). This could be because in the early $19^{\text {th }} \mathrm{C}$ most of the uncultivated lands were overgrown with cactus and as they were brought into lease and organized for systematic livestock production, fences of $B$. berryi were used. Voelcker (1893) had reported that hedges of B. berryi 


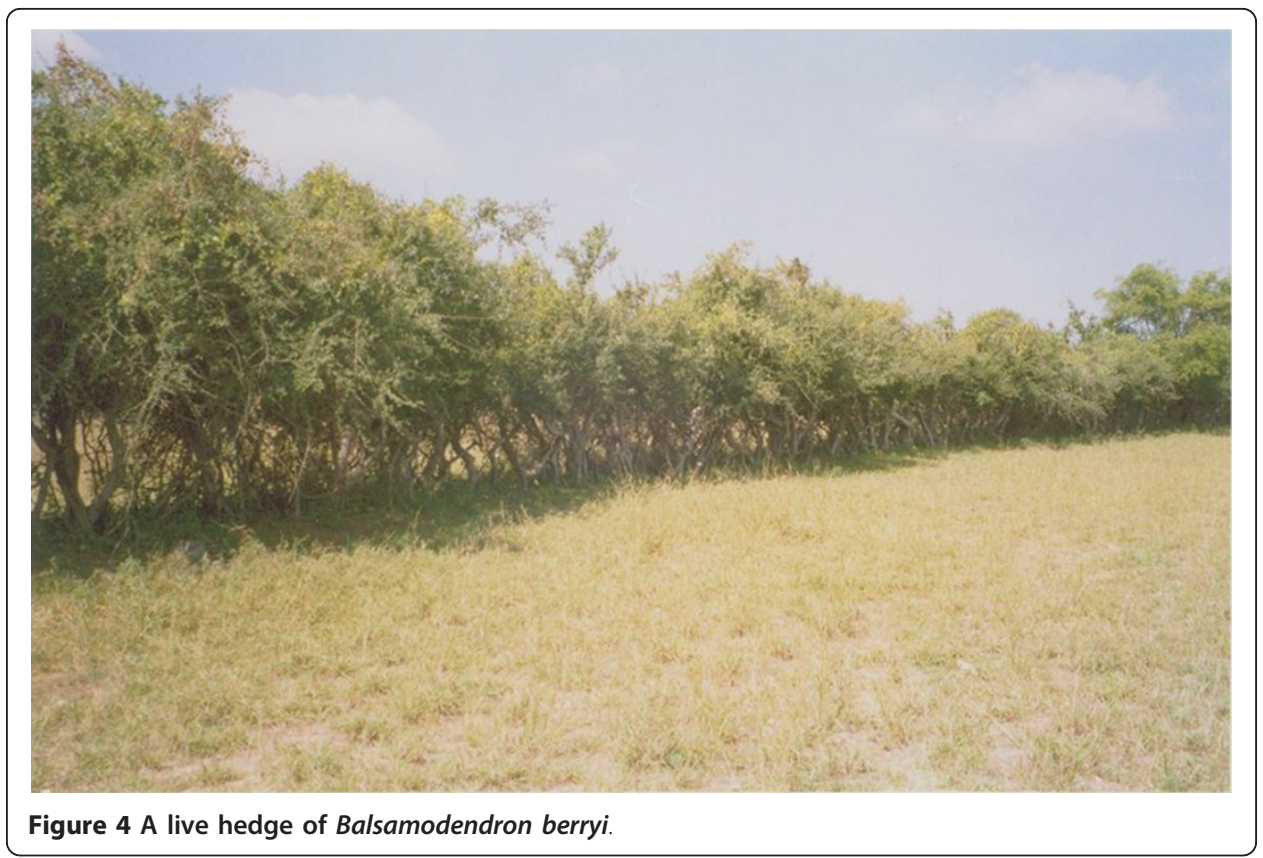

were found over the greater part of Coimbatore and cattle trespass was rare, cattle and crops were protected, large quantities of fuel supplied, and protection was given to growing trees. Under the paddock system of management, the grazing land is conveniently divided into paddocks of $2-4.5$ ha, although very large paddocks also exist (Table 6). The paddocks are separated by straight rows of $B$. berryi with a width of $0.6-0.75 \mathrm{~m}$ and height of $1.5 \mathrm{~m}$. There are 16 stalks every meter of length of the fence arranged in two rows of 8 each. The hedge is pruned every two years and gap filling is done by planting the stems during June-July. In Edaiyakottai village, Moringa oleifera trees and Agave americana are also grown among the live hedges. The fruits

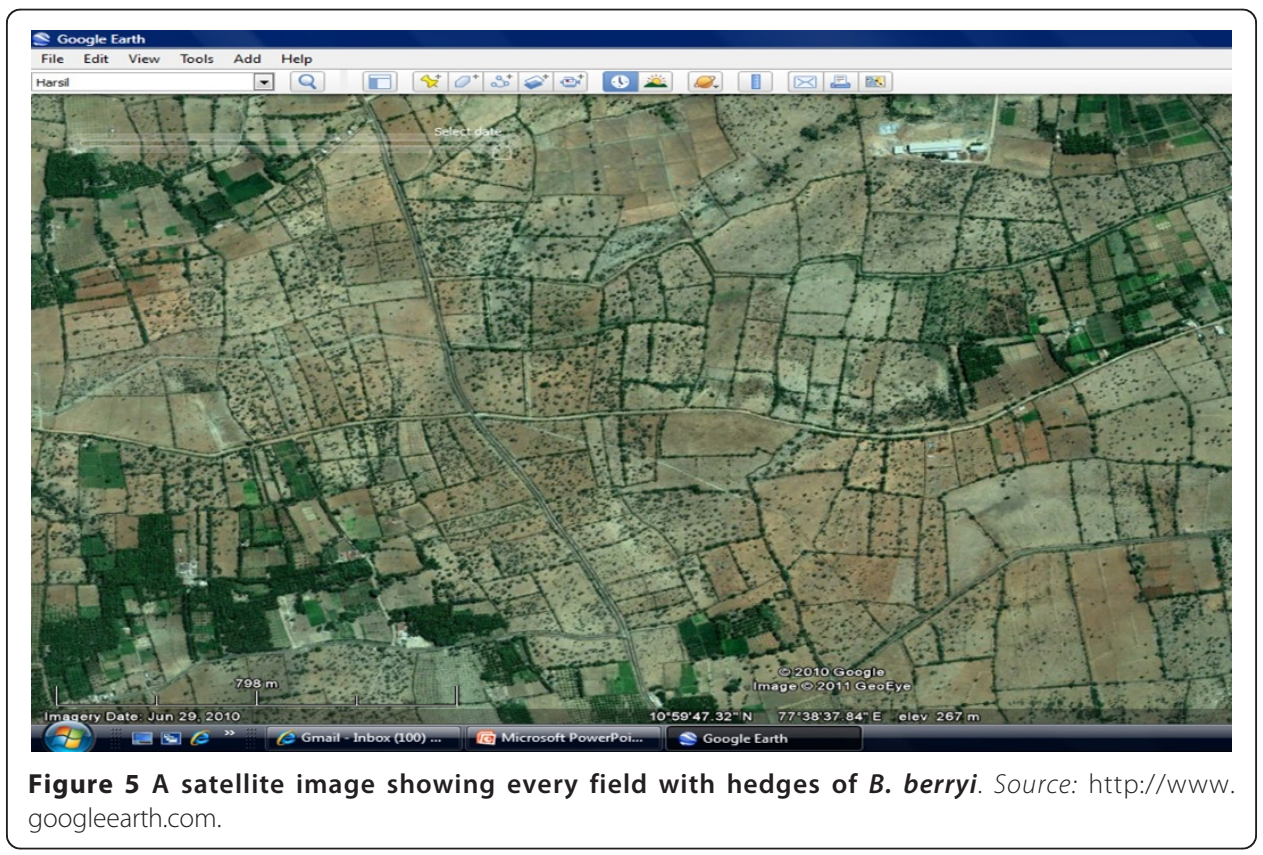


of Moringa are widely used in the traditional dishes of the region and provide additional income to the farmers. If the live hedges were to be replaced by barbed wire fences to secure the paddocks in the Kangayam region, it would cost approximately Rs. 1500 crore (USD 3378 million; 1 crore = INR10 million).

\section{Management of grasses and reseeding of pasture}

The dominant species in the grassland is Cenchrus which has a tussock density of 18-25 per sq. m. Re-seeding with seeds of Cenchrus is done by broadcasting to boost the forage yield in subsequent years. Cenchrus is a hardy grass species. Continuous grazing by the livestock inside the paddock leaves only the tussock from which new shoots come up upon the onset of rain. Eighty percent of the farmers reported that the pasture regenerates itself and does not require re-seeding. However, the rest of the farmers reported that re-seeding is done once in 4 to 6 years for better growth of grasses and to obtain higher biomass for livestock feeding.

\section{Rotational grazing of animals}

A paddock usually has 1 or 2 cattle/buffalo and 25-30 sheep. The animals are kept in the paddock day in and out for months together and they are rotated between the paddocks as per the fodder availability. This practice has been in vogue since the paddock system started. Nicholson (1887) also reported that grazing in these paddocks were regulated, pastures not overstocked and manure not removed from the ground, which resulted in excellent pasturage.

\section{Withholding animals from paddocks after rains to let the grass come up}

The rainfall in the grassland is not sufficient for cultivating cereal crops but encourages healthy growth of grasses. The grassland usually witness two flushes of grass growth. The minor one occurs after the rain in May and the major one in September-October (see Table 3 above). The animals are withheld from the pasture for one month after rain in May and September each, to let the pasture come up well. From mid June to mid September and from mid October to February, the animals remain on pasture alone and are not provided with any supplementary feed.

\section{Enrichment of forage with legumes and feeding practices}

The spread of dairy co-operatives in India has provided opportunities to millions of livestock keepers in the villages with one or two milch animals to obtain gainful employment and supplementary income by selling to the milk collection centres run by the co-operatives. The success of dairy co-operatives ushered in the 'White Revolution' in India which resulted in farmers taking more care of their animals. In many areas of the Kangayam grassland, progressive farmers plough the Cenchrus-dominated field in alternate years and sow them with seeds of Phaseolus trilobus at $12.5 \mathrm{~kg}$ per ha in October and a good crop of legume and grass comes up. Cattle and buffaloes are tethered in such fields. The animals are advanced a few meters every day to get the required intake. This practice continues from mid December till mid January and thereafter the mixed crop is harvested when still green, dried and stored for lean season feeding. 
The usual feeding practices for animals reared in the Kangayam grassland is to let them graze inside the paddocks from July to February. During this period animals are hardly given any supplementary feeding. However, from March to June, there remains almost nothing to graze inside the paddock which necessitates supplementary feeding for animals while still being inside the paddocks. The animals are fed with stored sorghum (Sorghum vulgare), pearl millet (Pennisetum typhoides) strover, tapioca (Manihot esculenta) leaves and the grass-legume hay. Sorghum is mostly obtained from the fields cultivated once in 4-5 years that is harvested at 50 percent flowering and stored for lean period feeding. Pearl millet and tapioca leaves are obtained from the fields under well irrigation. Lactating animals are given 1.5 to $2.0 \mathrm{~kg}$ rice bran mixed with wheat bran soaked in water overnight. Sheep are provided with 150-200 g of rice bran per head. Besides, the Acacia pods collected are also fed to animals. In periods of severe drought, palmyra leaves are lopped and fed to animals.

\section{Conclusions}

The study offers an insight into the historical development of the Kangayam grassland in a rain deficit region of south India. The Kangayam grassland in its present state of expanse has been in place for the last one hundred and fifty years. The grazing lands are all in private ownership and there are no communal grazing lands. The unoccupied wastelands were taken on lease by a growing human population between 1855 and 1881 and live fences of $B$. berryi were raised along the field boundaries. A system of rotational grazing of livestock in the paddocks was introduced which required minimal labour input. Careful management of the grazing paddocks was adhered to, among which was the withholding of animals for a month after initiation of rain to let the grass crop come up well and maintaining an optimum number of Acacia trees. Supplementary feeding is also practiced during lean period between March and June when the grass is almost completely grazed by the animals. The sustainable management of the grassland over a century also had some positive social spinoffs such as moderate growth in human population and a healthy female to male ratio. Alternatively, the necessity to check human population growth may also have arisen to prevent the fragmentation of land holdings, making them unsustainably small. Unfortunately, the sustainable management of the Kangayam grassland in a low rainfall region has remained unheard of beyond its immediate vicinity because people, places and events mostly make the news for the wrong reasons. A serene, sustainable system and society hardly makes any sensational news and thus remains obscured from the world at a large. This example provides some important lessons to emulate and replicate elsewhere in the areas of policy measures, technological interventions, and collective action to enhance the livelihood opportunities of livestock farmers.

\section{Acknowledgements}

The authors are thankful to Dr. P.S. Pathak, who pushed for and provided all the facility to undertake the study on Kangayam grassland. Prof. N. Kandasamy, who is a native of the Kangayam region, has given valuable suggestions to improve the manuscript. The authors are highly indebted to him. Thanks are also due to the anonymous reviewers for critically examining this article. Carol, the editor of this journal had cajoled us to come out with this article which we enjoyed writing and we are highly thankful to her. 


\section{Authors' contributions}

AK and SN collected the historical information of grassland development. NBB focused on the socioeconomic aspects and analyzed the data collected during survey. BKT carried out the vegetation study. All the authors participated in the survey of the grassland. All the authors have read and approved the final manuscript.

\section{Competing interests}

The authors declare that they have no competing interests.

Received: 31 January 2011 Accepted: 9 May 2011 Published: 9 May 2011

\section{References}

Anonymous 1908. Imperial Gazetteer of India: Provincial series Madras. Supt. of Govt. Printing, Calcutta 78.

Archana, S, Sharma, and Varun. 2009. Securing community tenure over common landsSouth Asia Pro Poor Livestock Policy Programme, New Delhi, India.

Buchanan, F. 1807. In A journey from Madras through the countries of Mysore, Canara and Malabar. Volume II. Blumar \& Co. London .

DFID 2002. Better livelihood for the poor people: The role of land policy. UK.

Foundation for Ecological Security 2009. Common Land and Poor Livestock-keepers: Experiences from Common Land Development in the States of Rajasthan and Madhya Pradesh in IndiaSouth Asia Pro Poor Livestock Policy Programme, New Delhi.

Gill, GJ. 1995. Major natural resource management concerns in South AsialFPRI, Washington D.C., USA.

GOI 2003. 17th Livestock censusMinistry of Agriculture, Government of India. New Delhi.

GOI 2009. India 2009Ministry of Information and Broadcasting, Government of India, New Delhi.

Gunn, WD. 1909. In Cattle of southern India. Bulletin No.60. Volume III. Department of Agriculture, Madras .

Hardin, G. 1968. The tragedy of commons'. Science 162(Dec.13): 1243-1248.

ILRI (International Livestock Research Institute) 2000. ILRI strategy to 2010: Making the livestock revolution work for the poor. ILRI, Nairobi, Kenya.

Kershaw, KA, and JHH Looney. 1985. Quantitative and Dynamic Plant EcologyEdward Arnold, Baltimore.

Littlewood, RW. 1936. Livestock of southern IndiaGovernment Press, Madras.

Maji, AK, GP Obi-Reddy, and D Sarkar. 2010. Degraded and Wastelands of India: Status and Spatial DistributionIndian Council of Agricultural Research, New Delhi.

Munro, DG. 1931. Grass Farming in CoimbatoreBulletin no.23, Government Press, Madras, India.

Nicholson, FA. 1887. Manual of the Coimbatore district in the Presidency of MadrasGovernment Press, Madras.

Patel, RK, and Kumbhara. 1983. 'Standardization of bovine unit'. Indian Journal of Animal Sciences 53(5): 547-550.

Pattabhiraman, D. 1958. The Kangayam breed of cattlePopular Education Publishing, Madras.

Planning Commission of India 2001. Report of the working group on Animal Husbandry \& Dairying for the Tenth Five Year Plan 2002-2007. Govt. of India, New Delhi.

Planning Commission of India 2007. Report of the Task Force on Grasslands and Deserts Grassland Task Force. Government of India, New Delhi.

Ramamurthy, V. 1986. History of Kongu: Prehistoric period to 1300 AD. International Society for the Investigation of Ancient Civilization, Madras, India.

Roberts-Pichette, P, and L Gillespie. 1999. Terrestrial vegetation biodiversity monitoring protocols. EMAN Occasional Pape Series, Report No. 9Ecological Monitoring Coordinating Office, Burlington, Ontario.

The Isles Project 2010. http://islesproject.com/2007/11/28/1750c-1860-from-common-to-private-land-enclosing-7million-acresie-21-of-england-via-over-5000-parliamentary-acts/. [accessed Oct 5, 2010].

Vivekanandan, P. 2007. Korangadu: A traditional pastureland farming system in the drylands of Tamil Nadu, South IndiaSustainable-agriculture \& Environmental Voluntary Action, Madurai, India.

Voelcker, JA. 1893. Report on the improvement of Indian agricultureEyre and Spottiswoode Publisher, London.

doi:10.1186/2041-7136-1-7

Cite this article as: Kumar et al:: Evolution of sedentary pastoralism in south India: case study of the Kangayam grassland. Pastoralism: Research, Policy and Practice 2011 1:7.

\section{Submit your manuscript to a SpringerOpen ${ }^{\odot}$ journal and benefit from:}

- Convenient online submission

- Rigorous peer review

- Immediate publication on acceptance

- Open access: articles freely available online

- High visibility within the field

- Retaining the copyright to your article

Submit your next manuscript at $\gg$ springeropen.com 